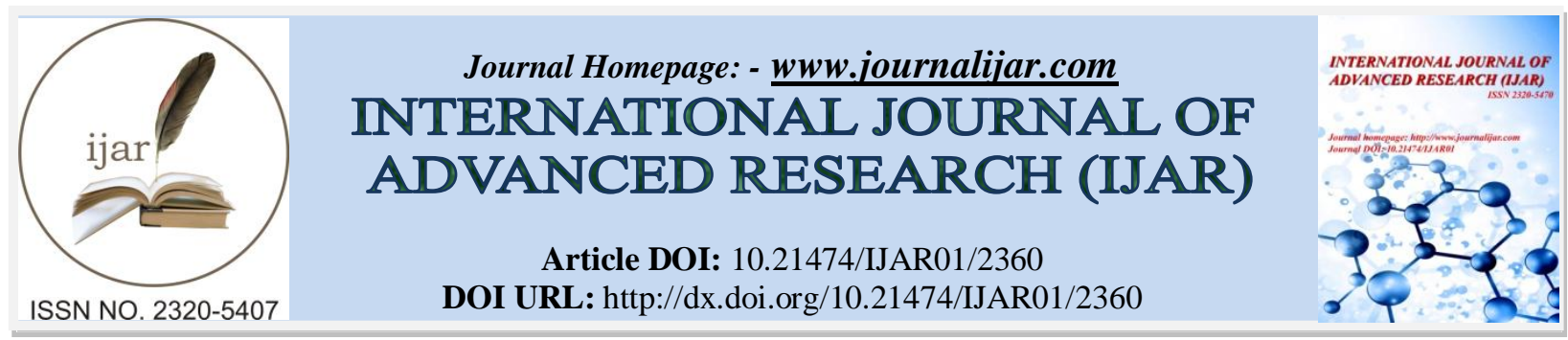

RESEARCH ARTICLE

\title{
A SCRUTINY ON THE LEISURE ACTIVITIES OF THE UNIVERSITY STUDENTS WHO ARE PRESERVICE TEACHERS and ON THEIR EXPECTATIONS FROM THE UNIVERSITY ACCORDING TO SOME VARIABLES.
}

Sirin Pepe ${ }^{1}$ and Aydın Pekel ${ }^{2}$.

1. Erenkoy Zeki Altındag Secondary School Physical Education and Sports Teacher.

2. Istanbul Gelisim University Physical Education and Sports School of Higher Education Istanbul.

\section{Manuscript Info}

Manuscript History

Received: 18 October 2016

Final Accepted: 20 November 2016

Published: December 2016

Key words:-

Leisure (free time), Preservice teacher, Expectation.

\section{Abstract}

The objective of this study is to assess the leisure activities of the students educated at Erciyes University who are preservice teachers and to compare their expectations from the University regarding their leisure activities.

The universe of the study is constituted by the students educated at Erciyes University who are preservice teachers and the sample group of the study consists of 300 students educated at different departments as determined through random method.

In line with the objective of the study, the validity and reliability of the questionnaire developed for the comparisons of the students' demographic information and leisure activities as well as their expectations from the university by Kirtepe (2011) were measured and the alpha $(\alpha)$ value was found $75.766 \%$. Consisting of 23 questions, the questionnaire was evaluated through the Likert Type Scale.

The data obtained from the questionnaires was recorded in a computer environment with a package program called IBM SPSS 22.0. T-test and One Way Anova were used as a statistical operation. Significance level was acknowledged as ,05.

According to the data obtained, and in view of the participations of the participants in the free time activities, it was determined that there had been no significant difference in terms of gender, age, and marital status while the income levels had yielded significant difference. When it comes to the expectation levels of the participants, significant difference was determined according to marital status and genders.

As a result, it was determined that the participations of the students educated at Erciyes University who are preservice teachers in leisure activities varied according income levels and their expectations regarding leisure activities varied according to gender, income level, and marital status. It is considered that according to such result, Erciyes University is unable to fulfill the expectations of the students educated at Erciyes University who are preservice teachers because of the insufficiency of the leisure activities it presents. 


\section{Introduction:-}

The thing with which a modern person plans every moment of him/her, which he/she wishes to experience fully, and for which he/she adjust himself/herself is time. Time is life itself and it is necessary to make use of time meaningfully.

In the $21^{\text {st }}$ century that we are experiencing, industrial and technological developments, dominance of machineries on humans, and increase in the welfare levels of them have caused the increase of interests in leisure (1).

Gradually increasing importance of time has demonstrated the importance of the time spent outside work; that is to say, leisure; and the requirement of ensuring its efficient utilization. In our daily lives, transformation of our works and other activities into boring and self-repeating efforts has made the leisure utilization activities a significant part of our lives and an instrument for recreation (2).

Leisure is defined as a unit of free time that remains outside the time that a person allocates to his/her responsibilities regarding work and to the care of himself/herself and of his/her family, where, therefore, there are no obligations (3).

While leisure activities are important for recreation and happiness of the individuals at any age, the behavioral properties gained through leisure activities during the university period are much more important for individuals.

University education is the most important process where the behavioral forms that will last for years take place. (4).

In our country, it appears that the universities differ from each other in terms of numerous amenities such as education and training means, their visions and missions, manner of their management, research and development, communication, informatics and transport means, data collection and processing, and knowledge production possibilities and capacities. This condition may cause differences in the expectations of students regarding both their universities and future. It becomes inevitable that the differences in the expectations of the newcomer students and their seniors are known and arrangements are performed accordingly and that new decisions are made and applied in terms of better and more realistic functioning of universities $(5,6)$.

In a scrutiny in the literature, studies that examine the leisure behaviors $(7,8)$ and expectations $(5,6)$ of the student groups educated at different universities were encountered. However, no study that examined both issues on the same group was determined. The purpose of this study is to assess the leisure activities and compare the expectations of prospective teachers.

\section{Material and Method:-}

\section{Constitution of the volunteers group:-}

This study has been performed for comparing the leisure activities of the students educated at different faculties of Erciyes University, who are prospective teachers, and the expectations of the students from the university relating to their leisure activities. The universe of the study is constituted by 700 students educated at different faculties of Erciyes University, who are preservice teachers and who have completed their formation education, and the sample group of the study consists of 300 students determined within the aforementioned group through random method.

\section{Data collection tools:-}

Socio -demographic information form:-

The form contains 4 personal questions regarding age, gender, marital status, and income level.

\section{Free Time and Expectation Inventory:-}

The volunteers taking part in the study were wanted to apply the free time inventory developed by Kirtepe. The questionnaire consists of 23 questions. The questions of the questionnaire were evaluated with the Likert Type Scale. In the Likert Type Scale, a five-level scale from the activities conducted "every time" toward activities performed "never" was used. The frequency of participating in the activities in this study consists of five distinct scales as "every time," "often," "sometimes," "rarely;" and "never;" or "I always participate," "I participate," "No idea," "I don't participate," an "I never participate." 
The work on the validity and reliability of the questionnaire has been performed by the author and the alpha ( $\alpha)$ value has been found $75.766 \%$ (1).

\section{Statistical Analyses:-}

The data obtained was recorded in a computer environment with a package program called IBM SPSS 22.0. As the statistical operation, T-test and One Way Anova were used. Significance level was accepted as ,05.

\section{Findings:-}

Following findings were obtained in this study performed on the free time behaviors and expectations of the prospective teachers.

Table 1:- Demographic Properties of the Participants.

\begin{tabular}{|c|c|c|c|}
\hline Variables & & $\mathbf{N}$ & f \\
\hline \multirow{4}{*}{ Age } & $18-20$ & 13 & 4,3 \\
\cline { 2 - 4 } & $21-23$ & 186 & 62 \\
\cline { 2 - 4 } & $24-27$ & 71 & 23,7 \\
\cline { 2 - 4 } & $28-31$ & 30 & 10 \\
\cline { 2 - 4 } & Total & 300 & 100 \\
\cline { 2 - 4 } & Married & 25 & 11,7 \\
\cline { 2 - 4 } & Unmarried & 257 & 85,7 \\
\cline { 2 - 4 } & Other & 300 & 2,7 \\
\hline \multirow{5}{*}{ Marital Status } & Total & 199 & 100 \\
\cline { 2 - 4 } & $500-750$ & 57 & 66,3 \\
\cline { 2 - 4 } & $751-1000$ & 18 & 19 \\
\cline { 2 - 4 } & $1001-1500$ & 26 & 7 \\
\cline { 2 - 4 } & 1501 and above & 300 & 8,7 \\
\hline \multirow{5}{*}{ Gender } & Total & 207 & 100 \\
\hline & Female & 93 & 69 \\
\hline
\end{tabular}

In Table 1, when the volunteers taking part in the study were examined according to their age values, it appears that $4,3 \%$ of them were at the age range being $18-20,62 \%$ being $21-23,23,7 \%$ being $24-27$, and $10 \%$ being $28-31$. It was determined relating to marital statuses that $11,7 \%$ were married, $85,7 \%$ were unmarried, and $2,7 \%$ were other. In the participants' income levels, 66,3\% were 500-750, 19\% were 751-1000, 7\% were 1001-1500, and 8,7\% were 1501 and above. When the participants of this study presented were examined according to their genders, it was determined that $69 \%$ were female and $31 \%$ were Male.

Table 2:- Activity and Expectation Levels as per Genders.

\begin{tabular}{|c|c|c|c|c|c|}
\hline Parameter & Gender & $\mathbf{N}$ & Mean \pm SD & $\mathbf{t}$ & p \\
\hline \multirow[t]{2}{*}{ Activity } & Female & 207 & $48,16 \pm 9,10$ & \multirow[t]{2}{*}{,28 } & \multirow[t]{2}{*}{, 595} \\
\hline & Male & 93 & $51,61 \pm 9,90$ & & \\
\hline \multirow[t]{2}{*}{ Expectation } & Female & 207 & $25,64 \pm 4,12$ & \multirow[t]{2}{*}{6,85} & \multirow[t]{2}{*}{, $009 *$} \\
\hline & Male & 93 & $24,51 \pm 5,32$ & & \\
\hline
\end{tabular}

It was determined in Table 2 that there had been no statistically significant difference in the participants' free time behaviors and expectations levels as per genders $(\mathrm{p}>0.05)$.

Table 3:- Activity and Expectation Levels as per Income Statuses.

\begin{tabular}{|c|c|c|c|c|c|c|}
\hline Parameter & Groups & $\mathbf{N}$ & $\mathrm{X} \pm \mathrm{SS}$ & $\mathbf{F}$ & Sig & p \\
\hline \multirow[t]{5}{*}{ Activity } & $500-750^{1}$ & 199 & $48,34 \pm 8,68$ & \multirow[t]{5}{*}{3.26} & \multirow[t]{5}{*}{0.22} & \multirow[t]{5}{*}{$1-2 *$} \\
\hline & $751-1000^{2}$ & 57 & $52,70 \pm 9,72$ & & & \\
\hline & $1001-1500^{3}$ & 18 & $48,39 \pm 11,08$ & & & \\
\hline & 1501 and above & 26 & $49,04 \pm 12,18$ & & & \\
\hline & Total & 300 & $49,23 \pm 9,48$ & & & \\
\hline \multirow[t]{5}{*}{ Expectation } & $500-750^{1}$ & 199 & $25,33 \pm 4,34$ & \multirow[t]{5}{*}{, 32} & \multirow[t]{5}{*}{, 81} & \multirow[t]{5}{*}{-} \\
\hline & $751-1000^{2}$ & 57 & $25,54 \pm 5,23$ & & & \\
\hline & $1001-1500^{3}$ & 18 & $25,17 \pm 4,22$ & & & \\
\hline & 1501 and above & 26 & $24,50 \pm 4,90$ & & & \\
\hline & Total & 300 & $25,29 \pm 4,55$ & & & \\
\hline
\end{tabular}


In Table 3, in terms of the university students' participation in the activities according to the income levels, statistical difference was determined among the ones with 500-750-lira and 751-1000-lira incomes ( $p<0,05)$, while no difference was determined in their expectation scores $(\mathrm{p}>0,05)$.

Table 4:- Activity and Expectation Levels as per Age.

\begin{tabular}{|c|c|c|c|c|c|c|}
\hline Parameter & Groups & $\mathbf{N}$ & $\mathrm{X} \pm \mathrm{SS}$ & $\mathbf{F}$ & Sig & $\mathbf{p}$ \\
\hline \multirow[t]{5}{*}{ Activity } & $18-20$ & 13 & $53,68 \pm 7,96$ & \multirow{5}{*}{1,28} & \multirow{5}{*}{,28 } & \multirow{5}{*}{-} \\
\hline & $21-23$ & 186 & $48,79 \pm 8,99$ & & & \\
\hline & $24-27$ & 71 & $49,89 \pm 8,20$ & & & \\
\hline & $28-31$ & 30 & $48,43 \pm 14,49$ & & & \\
\hline & Total & 300 & $49,23 \pm 9,48$ & & & \\
\hline \multirow[t]{5}{*}{ Expectation } & $18-20$ & 13 & $24,62 \pm 5,47$ & \multirow[b]{5}{*}{, 42} & \multirow[b]{5}{*}{,74 } & \multirow[b]{5}{*}{ - } \\
\hline & $21-23$ & 186 & $25,45 \pm 4,52$ & & & \\
\hline & $24-27$ & 71 & $25,30 \pm 4,16$ & & & \\
\hline & $28-31$ & 30 & $24,57 \pm 5,31$ & & & \\
\hline & Total & 300 & $25,29 \pm 4,55$ & & & \\
\hline
\end{tabular}

In Table 4, regarding the university students' participations in the activities and expectation levels according to the age groups, no statistical difference was determined $(\mathrm{p}>0,05)$.

Table 5:- Activity and Expectation Levels as per Marital Status.

\begin{tabular}{|c|c|c|c|c|c|c|}
\hline Parameter & Groups & $\mathbf{N}$ & $\mathrm{X} \pm \mathrm{SS}$ & $\mathbf{F}$ & Sig & $\mathbf{p}$ \\
\hline \multirow{4}{*}{ Activity } & Married & 25 & $46,91 \pm 10,67$ & \multirow{4}{*}{2,04} & \multirow[t]{4}{*}{,13 } & \multirow{4}{*}{-} \\
\hline & Unmarried & 257 & $49,67 \pm 8,92$ & & & \\
\hline & Other & 8 & $45,25 \pm 17,92$ & & & \\
\hline & Total & 300 & $49,23 \pm 9,48$ & & & \\
\hline \multirow[t]{4}{*}{ Expectation } & Married & 25 & $24,43 \pm 3,94$ & \multirow[t]{4}{*}{7,37} & \multirow[t]{4}{*}{,001** } & \multirow{4}{*}{$\begin{array}{l}1-3 \\
2-3\end{array}$} \\
\hline & Unmarried & 257 & $25,58 \pm 4,40$ & & & \\
\hline & Other & 8 & $19,75 \pm 7,80$ & & & \\
\hline & Total & 300 & $25,29 \pm 4,55$ & & & \\
\hline
\end{tabular}

In Table 5, in examining the university students' participation in the activities according to their marital statuses, no difference was determined ( $p>0,05)$, while, when it comes to expectation points, there was difference between the married and other groups and unmarried and other groups $(\mathrm{p}<0,001)$.

\section{Result and Discussion:-}

When the participations of the University students in the activities are examined in terms of their genders, it was determined that there was no statistically significant difference $(\mathrm{p}>0.05)$. In the study regarding the leisure satisfactions of the students of Ardahan and Lapa Universities, no statistical difference has been determined (9). In another study, $\mathrm{Lu}$ and $\mathrm{Hu}$ received statistical difference in the participation of the Chinese university students in activities. (10). In this study, it appears that the scores of participation in activities by male students are higher. It is contemplated that this condition results from the fact that the male students prefer a freer lifestyle and that they take less responsibility in fulfilling their assignments and responsibilities during their university education compared with the female students.

When the university students' expectation total points were examined statistically, significant difference was determined $(\mathrm{p}>0.05)$. A significant difference in favor of the female students was found in a scrutiny on gender variable for the future expectations of the students at Tuncer Vocational School of Higher Education (11). Consideration is that the higher expectation points of the female students than the male ones stem from their willingness to have their own freedom economically after being teachers and appointed.

In Table 3, in view of the university students' participation in activities according to their income levels, statistical difference was determined between those with the income of 500-750 liras and 751-1000 liras. While, in the respective literature, there is a study that states the participation in the free time activities in terms of economical status is directly proportional with the increase of income level (12), this study presented shows that the participation by those with 751-1000-lira income level in the free time activities is the higher value. It is considered that this condition is because of the fact that the participants with higher incomes have regular jobs and that those with 751-1000-lira income level are still dependants of their families. 
On Table 4, when the participation of university students in the activities according to the age groups was examined statistically, no statistical difference was determined $(p>0,05)$. In this study presented, despite the presence of statistically significant difference in the participation in the events, it is observed that the participation level of the 18-20 age group is higher than the other age groups. According to this condition, it can be said that age is an important factor in terms of spending free time by an individual.

In the examination of the university students' expectation levels according to the age groups statistically, no statistical difference was determined $(p>0,05)$. Presence of no significant difference among the age groups in the participations in terms of expectations is considered because of the fact that students have the same social environment and that they were preparing for exams.

No difference was determined in the statistical examination of the university students' participation in activities according to their marital statuses ( $>>0,05)$. Tel (13) has concluded in a study that marital status affected the types of preference in the participation in the activities for spending leisure times. According to the data obtained, it is considered that the fact that participation scores of the single ones in the free time events is higher than the other age groups is a normal condition.

When the university students' participation in the expectations was scrutinized in terms of the marital statuses statistically, difference between the married and other groups and unmarried and other groups was determined $(\mathrm{p}<0,001)$. In the respective literature, no studies relating to the students' expectations according to marital status have been encountered. In this study, it is considered that the married ones and others wish to spend their leisure at home with their family.

As a result, it was determined that the participations of the students educated at Erciyes University who are preservice teachers in leisure activities varied according income levels and their expectations regarding leisure activities varied according to gender, income level, and marital status. It is considered that according to such result, Erciyes University is unable to fulfill the expectations of the students educated at Erciyes University who are preservice teachers because of the insufficiency of the leisure activities it presents.

\section{References:-}

1. Kırtepe A,Fırat Havzasında Bulunan Bazı Üniversitelerde Öğrenim Gömekte Olan Öğrencilerin Boş Zamanlarını Değerlendirme Etkinliklerine Katılımlarının ve Beklentilerinin Tespiti,Yüksel Lisans,Sağlık Bilimleri Enstitüsü,Fırat Üniversitesi,2011:134.

2. Özdilek Ç,Demirel M,Harmandar D. Dumlupınar ve Sakarya Üniversitelerinde öğrenim gören Beden Eğitimi ve Spor Yüksekokulu öğrencilerinin boş zaman etkinliklerine katılım nedenleri ve düzeylerinin karşılaştırılması.Uluslararası İnsan Bilimleri Dergisi 2007:4:2.

3. Çolakoğlu T. Üniversite Öğretim Elemanlarının Boş Zaman Alışkanlıklarını Değerlendirmeleri Üzerine Bir Araştırma. Gazi Eğitim Fakültesi Dergisi 2005;24:247-258.

4. Mansuroğlu S.Akdeniz Üniversitesi Öğrencilerinin Serbest Zaman Özellikleri ve Dış mekan Rekreasyon Eğilimlerinin Belirlenmesi. Akdeniz Üniversitesi Zirat Fakültesi Dergisi 2002;15:(2):53-62.

5. Korukoğlu A. Üniversite Öğrencilerinin Eğitimlerinden Beklentileri Ege Üniversitesi İ.İ.B.F. Örneği.Süleyman Demirel Üniversitesi İ.İ.B.F. Dergisi 2003;8.(1):79-89.

6. Naralan A, Kaleli S. Üniversite Öğrencilerinin Üniversiteden Beklentileri ve Bölüm Menmuniyeti Araştırması Atatürk Üniversitesi Örneği. Organizasyon ve Yönetim Bilimleri Dergisi 2012;4 (1):

7. Aytaç Ö. Boş Zaman Üzerine Kurumsal Yaklaşımlar. Fırat Üniversitesi Sosyal Bilimler Dergisi 2002;1:231-260.

8. Lapa T, Ağyar E. Üniversite Öğrencilerinin Serbest Zaman Katılımlarına göre Algılanan Özgürlük. Spor Bilimleri Dergisi 2012;23.(1):24-33.

9. Ardahan F, Lapa TY, Üniversite Öğrencilerinin Serbest Zaman Tatmin Düzeylerinin Cinsiyet ve Gelir Düzeylerine Göre İncelenmesi. Hacettepe J. of Sport Sciences 2010 ;21:(4): 129-136.

10. Lu L, Hu CH. Personality, leisure experiences and happiness. Journal of Happiness Studies 2005;6: 325 - 342.

11. Tuncer M. Yükseköğretim Gençliğinin Gelecek Beklentileri Üzerine Bir Araştırma. International Periodical For The Languages, Literature and History of Turkish or Turkic Volume 2011;6:(2): 935-948.

12. Ardahan F, Lapa TY. Üniversite Öğrencilerinin Serbest Zaman Tatmin Düzeylerinin Cinsiyet ve Gelir Düzeylerine Göre İncelenmesi. Hacettepe J. of Sport Sciences 2010;21:(4):129-136.

13. Tel M, Öğretim Üyelerinin Boş Zaman Etkinlikleri Üzerine Sosyolojik Bir Araştırma Doğu Anadolu Örneği, Doktora, Sosyal Bilimler Enstitüsü, Frat Üniversitesi, 2007:272. 